\begin{tabular}{|l|l|}
\hline 2. To: (Receiving Organization) & $\begin{array}{l}\text { 3. From: (originating Organization) } \\
\text { SNF Storage Projects }\end{array}$ \\
\hline 5. Proj./Prog./Dept./Div.: & $\begin{array}{l}\text { 6. Design Authority/ Design Agent/Cog. } \\
\text { Engr.: }\end{array}$ \\
Spent Nuclear Fuel Project & K. E. Smith \\
\hline
\end{tabular}

8. Originator Remarks:

For Release

11. Receiver Remarks:
11A. Design Baseline Document?
[] Yes [X] no
4. Related EDT No.:

$N / A$

7. Purchase order No.:

$\mathrm{N} / \mathrm{A}$

9. Equip. /Component No.:

N/A

10. Systen/Bldg./Facil ity:

$N / A$

12. Major Assm. Dwg. No.: MCO

13. Permit/Permit Application No.: $N / A$

14. Required Response Date: N/A

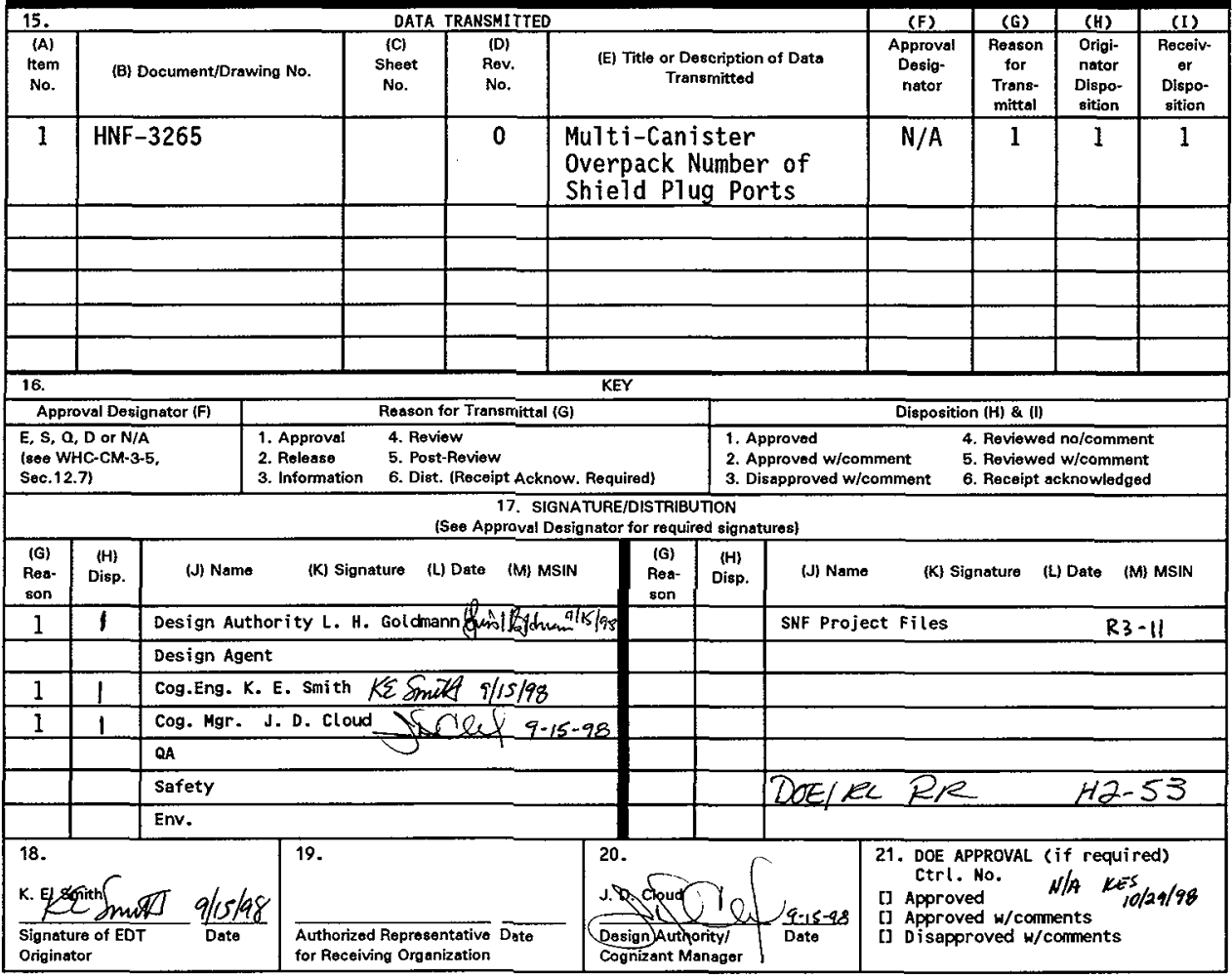


HNF-3265, Rev. 0

\section{Multi-Canister Overpack Number of Shield Plug Ports}

K. E. Smith

DE\&S Hanford, Inc., Richland, WA 99352

U.S. Department of Energy Contract DE-AC06-96RL13200

$\begin{array}{lll}\text { EDT/ECN: } & 625077 & \text { UC: } 600 \\ \text { Org Code: } & 2 \text { T340 } & \text { Charge Code: }{ }^{\text {LEO0 }} \\ \text { B\&R Code: } & \text { EW7040000 } & \text { Total Pages: } 6\end{array}$

Key Words: MC0, Shield Plug, Port \#1, Monitoring, Spent Fue1

Abstract: Port \#1 provides additional flexibility to address monitoring, sampling, and off-normal events. Deletion of the port now and then reintroduction at a later time will have negative cost and schedule impacts to the project. The port can easily be removed in the future, and the decision to eliminate the port should be made only after operating experience demonstrates conclusively that there is no practical use for the port. The comparison of the potential uses of port \#1 versus the cost savings associated with removal of the port does not justify elimination of the port at this time.

TRADEMARK DISCLAIMER. Reference herein to any specific commercial product, process, or service by trade name, trademark, manufacturer, or otherwise, does not necessarily constitute or imply its endorsenent, recommendation, or favoring by the United States Government or any agency thereof or its contractors or subcontractors.

Printed in the United states of America. To obtain copies of this document, contact: Document Control Services, P.0. Box 950, Mailstop H6-08, Richland WA 99352, Phone (509) 372-2420; Fax (509) 376-4989.
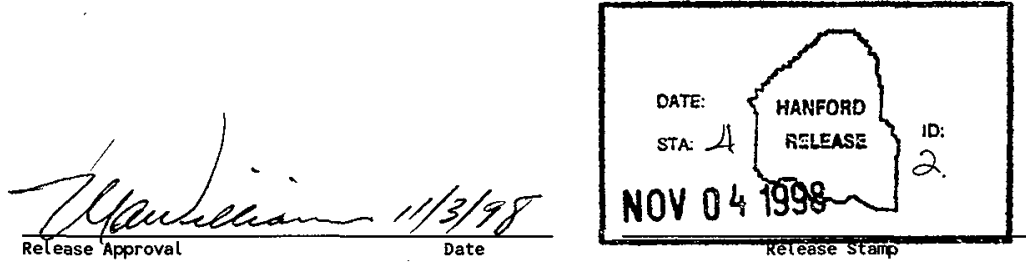

Approved for Public Release 
HNF-3265, Rev. 0

\section{Issue Closure Package}

Issue: $\quad$ NCO Number of Shield PJug Ports

Lead:

K. E. Smith

MCO Implementation

Manager, DE\&S Hanford

\section{Approvals:}

Chief Engineer:

A. M. Segrest

DE\&S Hanford

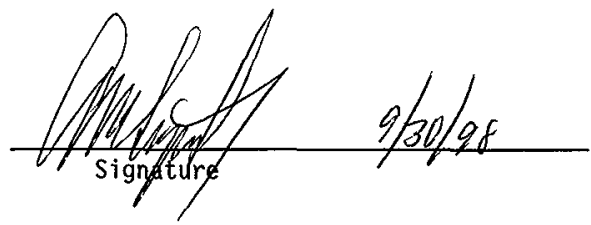

Technical Operations:

J. A. Swenson

Manager

DE\&S Hanford

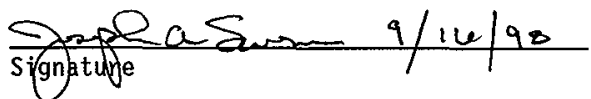

Construction Projects:

A. R. Hollins

Manager

DE\&S Hanford

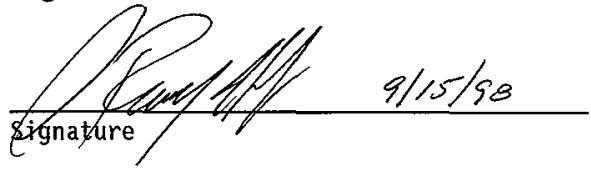

Nuclear Safety:

Robert G. Morgan Manager

DE\&S Hanford

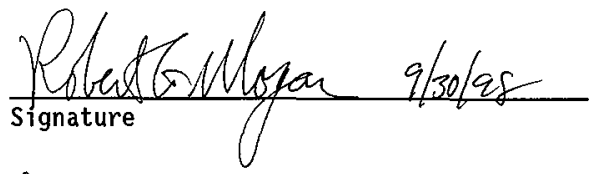

MCO Design Authority:

L. H. Goldmann

DE\&S Hanford

Gurblsolduam a/15/98

Signature 
HNF-3265, Rev. 0

\author{
MULTI-CANISTER OVERPACK
}

NUMBER OF SHIELD PLUG PORTS

\title{
Introduction
}

Incorporation of the MCO Sealing Strategy eliminated the staging of "pressuremanaged" MCOs in the Canister Storage Building (CSB). The process pressure relief valve previously contained in shield plug port \# 1 was designed to provide the ability to manage the pressure within the MCO in order to preclude a full 150 psig blow-down through the safety class rupture disk. With elimination of the pressure managed $M C O$ strategy at the CSB, the relief valve is no longer needed in the MCO design. With the elimination of the pressure relief valve, the potential future utilization of port \# 1 should be evaluated against the fabrication cost savings associated with deleting the port.

\section{Port Sunmary}

The MCO shield plug is equipped with four ports. An isometric sketch is at the end of this paper showing the layout of the ports within the shield plug. A summary of each port follows:

\section{Port \# 1}

This port \# 1 is described below in the Discussion section.

\section{Port \# 2}

This port has a 1 inch diameter passage way which is connected to the MCO internal high efficiency particulate air (HEPA) filter manifold.

The primary use of this port is for process gas removal during the vacuum drying of the MCO at the cold vacuum drying (CVD) facility. The CVD facility vacuum pump is connected to this port and it is used for water vapor and other gas removal. This port is also used while the MCO is in the sealed cask on transfer to the CVD. It allows the gas inside the MCO to interact with the atmosphere inside the cask.

The secondary use of this port is for gas sampling of the MCO at the canister storage building (CSB) prior to the cover caps being welded onto the MCO.

\section{Port \# 3}

This port has a 0.59 inch diameter passage way and is connected to a $2 \mathrm{~mm}$ strainer at the bottom of the MCO.

The primary use of this port is for removal of bulk water from the MCO at the CVD facility. 
HNF-3265, Rev. 0

The secondary use for this port is for the introduction of gasses into the MCO.

other possible uses include reflooding the MCO with water should the need arise.

\section{Port \# 4}

This port has a 1 inch diameter passage way which is connected to the $2 \mathrm{~mm}$ strainer inside the armored chamber at the shield plug.

The primary use of this port is for the pressure relief rupture disk in the event of a flooded runaway corrosion event occurs inside the $\mathrm{MCO}$. This event is possible any time the MCO is fueled and flooded with water. The MCO is assembled flooded at the basins and the bulk water is removed in the CVD facility.

The secondary use of this port is as a backup port for the vacuum drying of the MCO in the event port \# 2 or the MCO internal HEPA fiTters become inoperational, blinded, or blocked.

This port also defines the release by a blow down, if any, from the MCO in the case of disk actuation in the port appliance due to excessive pressure.

\section{Discussion}

Port \# 1 has a 1 inch diameter passageway through the shield plug which is connected to the MCO internal high efficiency particulate air (HEPA) filter manifold. The current MCO design shows a threaded port plug and seal in place to blank-off the port. Potential uses of this port include the following:

- $\quad$ HEPA filtered relief

- Sampling, verification and/or adjustment of MCO gas content and pressure prior to the MCOs being welded or shipped off-site. This includes the capability to access the MCO through the cover cap penetration and port \# 1 without removal of the welded cover cap

- Umbilical connection for "on-line" surveillance of MCOs

- Te11-tale pressure indication device on the MCOs

- Remote broadcast/sensing devices on the MCOS

- Other monitoring schemes associated with the MCOS

The uses above would facilitate:

- monitoring of the MCOS at the CSB

- upset recovery of the MCOS

- maintaining a fall-back capability (i.e. cavity space in and threaded connection to the shield plug) for future use 
HNF-3265, Rev. 0

While the exact use of port \# 1 has not been identified at this time, this port provides considerable flexibility to address numerous monitoring applications and recovery from off-normal events. The \# 1 port can be changed to suit without affecting facility (CVD or CSB) process connections or easily removed from the design in the future, should none of the potential uses mentioned above be required. However, removing the port now and then having to reinstate the port in the future would adversely impact the MCO Topical Report, MCO Design Report, dose analysis, and fabrication contract. Any increase in fabrication scope after award of the contract would be costly. Impacts due to later reintroduction of port \# 1 could also cause schedule delays.

The potential cost savings of eliminating the port, threaded plug, shield plug passageways, cover plate, cover bolts, and seals is estimated at about $\$ 500$ per MCO for a total of $\$ 200,000$ for the $400 \mathrm{MCOs}$. Given the potential uses of the port, it is prudent to retain the port at this time. Future consideration for removal of the port can be made sometime after the fuel removal campaign is initiated and operating experience confirms that the potential uses for the port are not needed. Additionally, recovery plans should be developed and approved prior to making the decision to el iminate this port. The fabrication contract bid documents will require all bidders to provide a fixed price credit for deletion of port \#1. This will ensure that the full value associated with deleting the port is realized, should it be determined in the future that the port is not needed.

\section{CONCLUSION}

Port \# 1 provides additional flexibility to address monitoring, sampling, and off-normal events. Deletion of the port now and then reintroduction at a later time will have negative cost and schedule impacts to the project. The port can easily be removed in the future, and the decision to eliminate the port should be made only after operating experience demonstrates conclusively that there is no practical use for the port. The comparison of the potential uses of port \# 1 versus the cost savings associated with removal of the port does not justify elimination of the port at this time. 
HNF-3265, Rev. 0

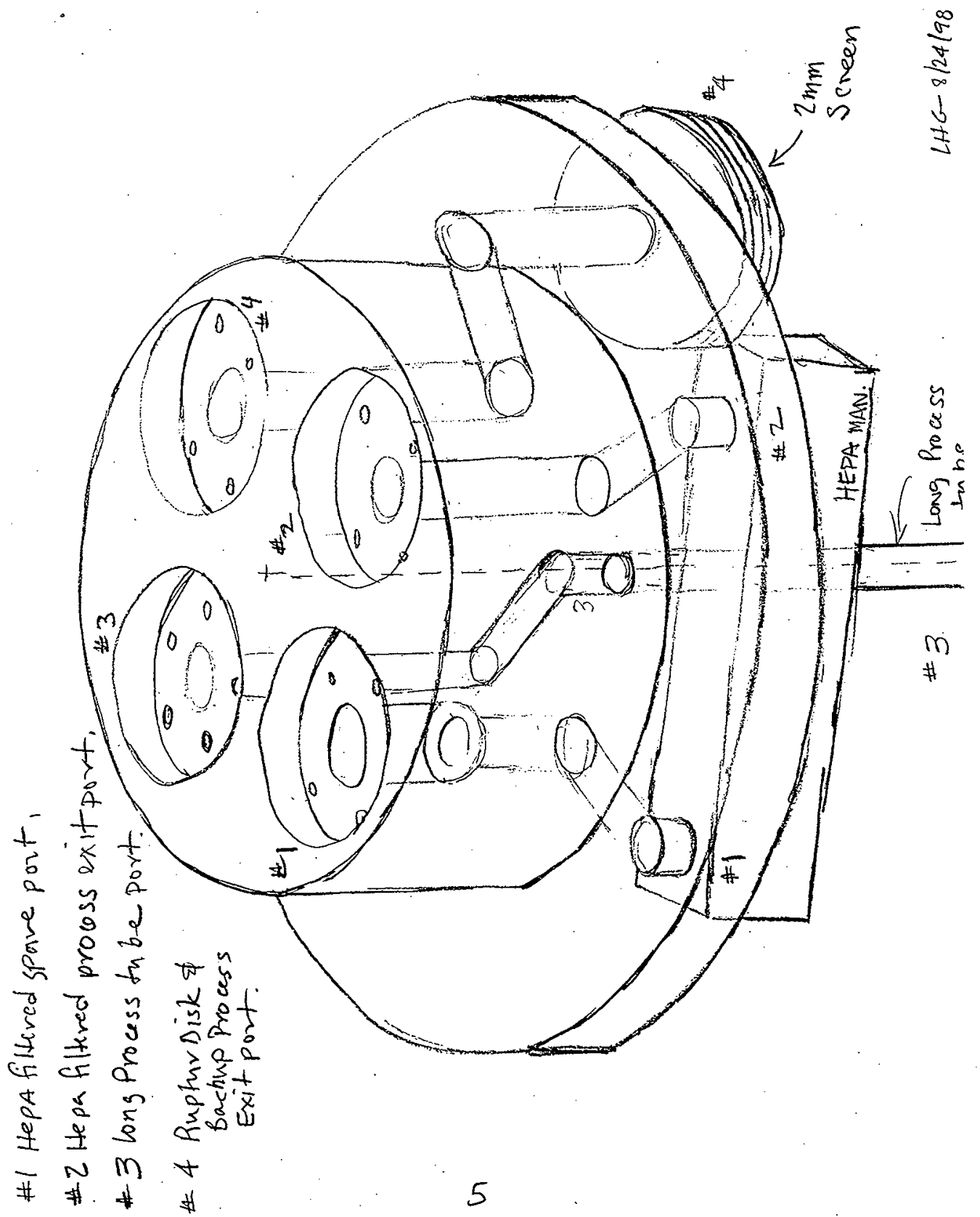




\section{DISTRIBUTION COVERSHEET}

Subject: MCO ISSUE PAPERS PER ATTACHED DISTRIBUTION INDEX

\section{DISTRIBUTION}

\begin{tabular}{|c|c|c|c|}
\hline Name & Location & & w/att \\
\hline \multicolumn{4}{|c|}{ Spent Nuclear Fuel Project } \\
\hline W. C. Alaconis & R3-86 & & $\mathrm{X}$ \\
\hline G. D. Bazinet & S8-06 & & $X$ \\
\hline J. D. Cloud & R3-86 & & $\mathrm{X}$ \\
\hline D. R. Duncan & R3-86 & & $X$ \\
\hline J. R. Frederickson & R3-86 & & $X$ \\
\hline L. J. Garvin & R3-26 & & $X$ \\
\hline L. H. Goldmann & R3-86 & & $X$ \\
\hline A. R. Hollins, Jr. & $\mathrm{R} 3-86$ & & $X$ \\
\hline C. R. Hoover & $\mathrm{R} 3-86$ & & $\mathrm{X}$ \\
\hline J. J. Irwin & R3-86 & & $X$ \\
\hline B. D. Lorenz & $\mathrm{R} 3-26$ & & $\mathrm{X}$ \\
\hline C. R. Miska & R3-86 & & $X$ \\
\hline R. G. Morgan & $\mathrm{R} 3-26$ & & $\mathrm{X}$ \\
\hline R. P. Omberg & $\mathrm{H} 0-40$ & & $X$ \\
\hline A. M. Segrest & R3-11 & & $X$ \\
\hline R. A. Sexton & R3-86 & & $X$ \\
\hline K. E. Smith & $\mathrm{R} 3-86$ & & $\mathrm{X}$ \\
\hline J. A. Swenson & R3-11 & & $X$ \\
\hline N. H. Williams & R3-11 & & $\mathrm{X}$ \\
\hline Project File & R3-11 & . & $x$ \\
\hline \multicolumn{4}{|c|}{ U.S. Department of Energy } \\
\hline C. B. Loftis & S7-41 & & $\mathrm{X}$ \\
\hline P. G. Loscoe & S7-41 & & $X$ \\
\hline E. D. Sellers & S7-41 & & $X$ \\
\hline J. B. Sullivan & S7-41 & & $\mathrm{X}$ \\
\hline
\end{tabular}




\section{DISTRIBUTION INDEX}

The Multi-Canister Overpack Issue papers listed below are being distributed as a package to facilitate future reference and use by SNF Project personnel. The following issue papers are attached:

1. HNF-2876, Oxygen Gettering Issue Closure Package

2. HNF-3265, MCO Number of Shield Plug Ports

3. HNF-3399, MCO Necessity of the Rupture Disk

4. HNF-3267, MCO Dual Pressure Rating

5. HNF-3293, MCO Ultrasonic Examination of Closure Weld

6. HNF-3354, MCO Monitoring Issue Closure Package and HNF-3312, MCO Monitoring Activity Description

7. HNF-3292, MCO Sealing Configuration

8. HNF-3266, MCO Design Pressure Rating

9. HNF-3255, ASME Code Requirements for MCO Design and Fabrication

10. HNF-3398, MCO Inservice Inspection and Maintenance

11. HINF-3420, MCO Internal HEPA Filters

12. HNF-3036, Low Reactive Surface Area Issue Closure Package

13. HNF-3270, MCO Pressure Testing 